\title{
Assessment of the normal anal position index (API) of Indonesian neonates
}

\author{
Yudi Suryana*, Akhmad Makhmudi \\ Pediatric Surgery Division, Department of Surgery, Faculty of Medicine, Publik Health, and \\ Nursing, Universitas Gadjah Mada/Dr. Sardjito General Hospital, Yogyakarta, Indonesia
}

DOI: http://dx.doi.org/10.19106/JMedScie/005004201807

\section{ABSTRACT}

The existing anal position index (API) data appear to vary among the ethnic differences. Until now, however, the normal API has not been studied in Indonesia. This study aimed to determine the normal value of the API in Indonesian newborns This cross-sectional study was conducted on 62 neonates ( 29 males and 33 females) without any malformation at Pediatric Surgery Division, Department of Surgery, Dr. Sardjito General Hospital, Yogyakarta during the period September to October 2012. The position of the anus was numerically defined by the API, which is the ratio of anus-fourchette distance in females and anus-scrotum distance in males to the distance between coccyx and fourchette/scrotum. To make correct measurements, transparent adhesive tape was used longitudinally on midperinum in a way that it covered the anus. Then fourchette/scrotum, anus center and the lower margin of coccyx were marked on it. Distances marked on each tape were then measured with the standard ruler. Relationship between API and other parameters were analyzed. The API values were $0.46 \pm 0.05$ (95\% Cl: $0.44-0.48)$ for newborn males and $0.37 \pm 0.07$ (95\% Cl: 0.35-0.39) for newborn females. The difference of API between males and females was significant $(p=0.000)$. API had no significant correlation with gestational age $(p=0.350)$ and birth weight $(p=0.650)$. Our data suggested the API, which is sex dependent, provides a reliable parameter for determining the position of the anus. API has no correlation with gestational age and birth weight. The determination of normal API in older infants is required to determine whether the API is affected by age.

\section{ABSTRAK}

Data indeks posisi anal (API) yang ada tampaknya bervariasi di antara etnis yang berbeda. Namun, hingga saat ini, API normal belum ditetapkan di Indonesia. Penelitian ini bertujuan untuk menentukan nilai normal API pada bayi baru lahir di Indonesia. Penelitian potong lintang ini dilakukan pada 62 neonatus (29 laki-laki dan 33 perempuan) tanpa malformasi Divisi Bedah Anak, Departemen Bedah, RSUP Dr. Sardjito, Yogyakarta antara September hingga Oktober 2012. Posisi anus secara numerik ditentukan oleh API, yang merupakan rasio jarak anus-fourchette pada wanita dan jarak anus-skrotum pada pria yaitu jarak antara coccyx dan fourchette/skrotum. Untuk membuat pengukuran yang benar, pita perekat transparan digunakan secara longitudinal pada midperinum sedemikian rupa sehingga menutupi anus. Fourchette/skrotum, anus center dan margin bawah coccyx ditandai dengan pita tersebut. Jarak yang ditandai pada setiap pita kemudian diukur dengan penggaris standar. Hubungan antara API dan parameter lainnya juga dianalisis. Nilai API adalah $0,46 \pm 0,05(95 \% \mathrm{Cl}, 0,44-0,48)$ untuk pria yang baru lahir dan $0,37 \pm 0,07$ $(95 \% \mathrm{Cl}, 0,35-0,39)$ untuk wanita yang baru lahir. Terdapat perbedaan API yang bermakna antara pria dan wanita $(p=0,000)$. API tidak memiliki korelasi yang signifikan dengan usia kehamilan $(p=0,350)$ dan berat lahir $(p=0,650)$. Data menunjukkan bahwa API, yang bergantung pada jenis kelamin, merupakan parameter andal untuk menentukan posisi anus. API tidak memiliki korelasi dengan usia kehamilan dan berat lahir. Penentuan API 
normal pada bayi yang lebih tua diperlukan untuk menentukan apakah API dipengaruhi oleh usia.

Keywords : anal position index - sex - gestational age - Indonesia - neonate

\section{INTRODUCTION}

Anterior displaced anus (ADA) or anterioranus, an anatomical variation of the normal position of the anus in the perineum, is due to malformation of the mid-portion of the external sphincter and weakness of corresponding segment of the anal canal. ${ }^{1}$ Its diagnosis usually goes undetected in neonates. Some studies showed that ADA is a frequent cause of constipation during infancy. ${ }^{2,3}$ However, other reports haven't seen any correlation between ADA and constipation. ${ }^{4,5}$

A study conducted by Reisner $e t$ al. in 1984 first proposed the anal-position index (API) as a reliable method of determining the normal positioning of the anus. ${ }^{6}$ Subsequent to this, several reports in different countries have showed reference data in the API format. ${ }^{5,7-11}$ Until now, however, the normal API has not been studied in Indonesia. The aim of this study was to determine the normal value of the API in Indonesian newborns.

\section{MATERIALS AND METHODS Subjects}

This cross-sectional study was conducted on 62 neonates (29 males and 33 females) at Pediatric Surgery Division, Department of Surgery, Dr. Sardjito General Hospital, Yogyakarta during the period September to October 2012. All subjects were selected at random and had no known anomalies, with especially attention paid to anomalies of the perineum.

\section{Anal position index measurement}

The gestational age and sex were recorded, and birth weight and API were measured in the physical examination. API is the ratio of anus-fourchette distance in females and anus-scrotum distance in males to the distance between coccyx and fourchette/scrotum (FIGURE 1). To make correct measurements, transparent adhesive tape was used longitudinally on midperinum in a way that it covered the anus. Then fourchette/scrotum, anus center and the lower margin of coccyx were marked on it. Distances marked on each tape were then measured with the standard ruler. Relationship between API and other parameters were analyzed.

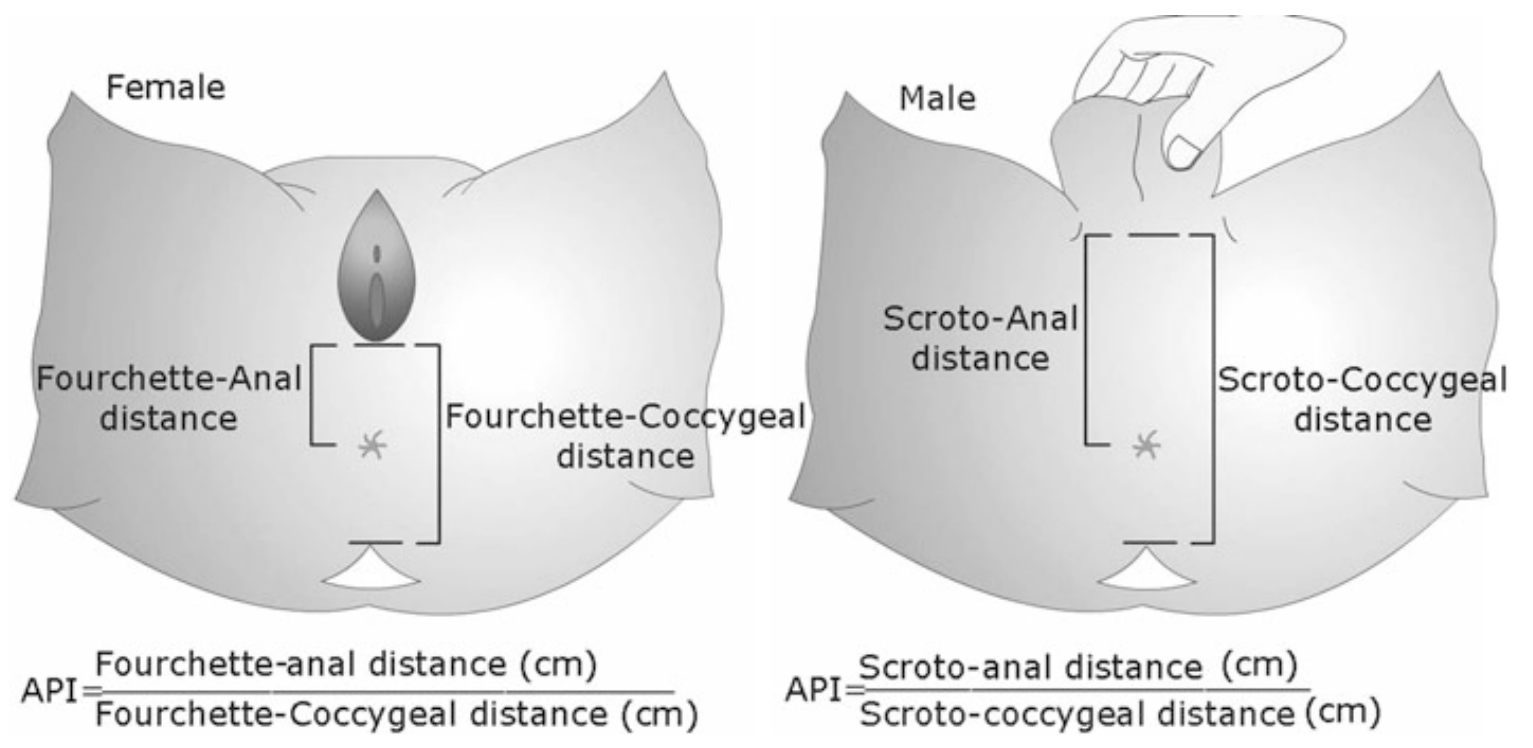

FIGURE. 1. Measurement of the anal position index (API) for male and female newborns. ${ }^{(9)}$ 


\section{Statistical analysis}

The quantitative variables studied were presented as mean \pm standard deviation (SD). Comparisons between the different groups were performed by student's t-test. The statistical significance represent with $p$ value of $<0.05$. The data analysis was performed using SPSS Statistics version 18(SPSS Inc.).

\section{RESULTS}

In this study, $29(46.8 \%)$ were males and $33(53.2 \%)$ were females. All neonates were 1-3 days old. The majorities (88.7\%) of newborns were term newborns and $11.3 \%$ were premature newborn; and no post-term newborn was recorded. There were no significant differences of gestational age and birth weight between sexes. Demographic characteristics of 62 newborns allocated by sex are shown in TABLE 1.

TABLE 1. Demographic characteristic of male and female newborns

\begin{tabular}{lcccc}
\hline Variable & All & Male & Female & p \\
\hline Gestational age (mean \pm SD weeks) & $37.82 \pm 1.6$ & $37.93 \pm 1.7$ & $37.73 \pm 1.5$ & 0.617 \\
Preterm [n (\%)] & $7(11.3)$ & $2(6.9)$ & $5(15.2)$ & \\
Term newborn [n (\%)] & $55(88.7)$ & $27(93.1)$ & $28(84.8)$ & \\
Post term [n (\%)] & 0 & 0 & 0 & \\
Birth weight (mean \pm SD g) & $2883.7 \pm 561.0$ & $2993.1 \pm 619.6$ & $2787.6 \pm 493.7$ & 0.152 \\
\hline
\end{tabular}

The API values were $0.46 \pm 0.05(95 \%$ CI, 0.44-0.48) for male and $0.37 \pm 0.07$ (95\% CI, 0.35-0.39) for female newborns. The difference of API between males and females was significant $(\mathrm{p}=0.000)$ (TABLE 2). API had no significant correlation with gestational age $(\mathrm{p}=0.350)$ and birth weight $(p=0.650)$ (data not shown).

TABLE 2. Measurement of anal position index (API) in male and female newborns

\begin{tabular}{lccccc}
\hline Variabale & Mean \pm SD & CI 95\% & Minimum & Maximum & $\mathrm{p}$ \\
\hline Scrotoanus $(\mathrm{mm})$ & & & & & \\
- Male & $23.45 \pm 2.95$ & $23.38-24.52$ & 13 & 28 & 0.000 \\
- Female & $13.33 \pm 3.71$ & $12.06-14.60$ & 8 & 23 & \\
Total & $18.06 \pm 6.09$ & $16.54-19.58$ & 8 & 28 & \\
Scrotococcyx (mm) & & & & & \\
- Male & $50.76 \pm 5.93$ & $48.60-52.92$ & 31 & 58 & 0.000 \\
- Female & $36.67 \pm 10.12$ & $33.20-40.12$ & 21 & 63 & \\
Total & $43.26 \pm 10.95$ & $40.53-45.99$ & 21 & 63 & \\
API & & & & & \\
- Male & $0.46 \pm 0.06$ & $0.44-0.48$ & 0.40 & 0.60 & 0.000 \\
- Female & $0.37 \pm 0.07$ & $0.35-0.39$ & 0.25 & 0.54 & \\
Total & $0.41 \pm 0.08$ & $0.39-0.43$ & 0.25 & 0.60 & \\
\hline
\end{tabular}




\section{DISCUSSION}

ADA has many synonyms such as anterioranus, anterior placed anus, short perineal body, or anterior ectopic anus. Previously, the diagnosis of ADA relied on inspection only, which its results may vary widely depending on the inspecting physician's methods. ${ }^{2,3}$ The quantitative measurement of normal anus position, which first reported by Reisner et al., was called anal position index (API). ${ }^{6}$ This measurement will help identify the presence of ADA in newborns.

However, abnormal API is never reasonable to decide for surgery. Indeed, neonates found to have this anomaly should be examined for possible defecation disorders. Therefore, their parents and pediatrician should be aware that, to prevent constipation, rigorous hygiene and dietary habits would be necessary. If chronic constipation occurred, patient should be referred to a pediatric surgeon for examination of muscle complex evaluation. Accordingly, the only indication of surgery in these patients was abnormal muscle complex. ${ }^{10-11}$

Previous study reported that there was no relationship between ethnic differences and API. ${ }^{7}$ Our study showed that the API values of our newborns were similar to those from previous reports, ${ }^{4-10}$ though differences still exist. Disparities among studies could be due to the different methods used ${ }^{8}$ or due to racial differences. Multiple measurements should be conducted for determination of API, which may reduce the bias due to human errors.

\section{CONCLUSIONS}

Our data suggested the API, which is sex dependent, provides a reliable parameter for determining the position of the anus. API has no correlation with gestational age and birth weight. The determination of normal API in older infants is required to determine whether the API is affected by age.

\section{ACKNOWLEDGEMENTS}

We would like to thanks all the children who contribute in this study's data collection. We also would like to thanks Dr. Sardjito General Hospital for the permission of this study.

\section{REFERENCES}

1. Upadhyaya P. Mid-anal sphincteric malformation, cause of constipation in anterior perineal anus. J Pediatr Surg 1984; 19(2):183-6.

http://dx.doi.org/10.1016/S0022-3468(84)80445-5

2. Hendren WH. Constipation caused by anterior location of the anus and its surgical correction. J Pediatr Surg 1978; 13(6):505-12.

http://dx.doi.org/10.1016/S0022-3468(78)80315-7

3. Leape LL, Ramenofsky ML. Anterior ectopic anus: a common cause of constipation in children. J Pediatr Surg 1978; 13(6):627-30.

http://x.doi.org/10.1016/S0022-3468(78)80105-5

4. Herek O, Polat A. Incidence of anterior displacement ofthe anus and its relationship to constipation in children. Surg Today 2004; 34(2):190-2.

http://dx.doi.org/10.1007/s00595-003-2656-6

5. Bar-Maor J, Eitan A. Determination of the normal position of the anus (with reference to idiopathic constipation). J Pediatr Gastroenterol Nutr 1987; 6(4):559-61.

http://dx.doi.ong/10.1097/00005176-198707000-00012

6. Reisner SH, Sivan Y, Nitzan M, Merlob P. Determination of anterior displacement of the anus in newborn infants and children. Pediatrics 1984; 73(2):216-7.

7. Genc A, Taneli C, Tansug N, Kasirga E, Yilmas D, Kucukoglu T, et al. Evaluation of the location of the anus by a modified technique in the neonate. J Pediatr Surg 2002; 37(1):80-2.

http://dx.doi.org/10.1053/jpsu.2002.29432

8. Davari HA, Hosseinpour M. The anal position index: a simple method to define the normal position of the anus in neonate. Acta Paediatr 2006; 95(7):877-80. 
http:/dx.doi.org/10.1111/j.1651-2227.2006.tb02360x

9. Rerksuppaphol S, Rerksuppaphol L. Normal anal position index in Thai newborns. J Med Assoc Thai 2008; 91(12):1839-44.

10. Chan WT, Lee HC, Wang WN, Yeung CY, Jiang CB. Determination of the normal position of the anus in Taiwanese infants. Pediatr Neonatol 2009; 50(4):158-61. http://dx.doi.org/10.1016/S1875-9572(09)60055-3
11. Núñez-Ramos R, Fabbro MA, GonzálezVelasco M, Núñez Núñez R, Romanato $B$, Vecchiato L, et al. Determination of the anal position in newborns and in children with chronic constipation: comparative study in two European healthcare centres. Pediatr Surg Int 2011; 27(10):1111-5.

http://dx.doi.org/10.1007/s00383-011-2914-4 